\title{
Pemahaman Petani Tentang Budidaya Kopi Arabika dan Pengaruhnya Terhadap Produktivitas Hasil Panen
}

\section{Farmers Understanding about Cutivation of Arabica Coffee and Its Effect on Crop Productivity}

\author{
I Komang Agus Suara, I Wayan Widia, Ida Bagus Putu Gunadnya \\ Program Studi Teknik Pertanian, Fakultas Teknologi Pertanian, Unud \\ Email: agussuara90@gmail.com
}

\begin{abstract}
Abstrak
Tujuan penelitian ini adalah untuk mengetahui tingkat pemahaman petani terhadap budidaya kopi dan pengaruhnya terhadap produktivitas. Aspek budidaya yang diamati meliputi persiapan lahan, pengatur intensitas cahaya, teknik tanam, pemuliaan tanaman, aplikasi pupuk, pengendalian hama tanaman, peremajaan tanaman dan aspek pemanenan kopi. Penelitian ini melibatkan 45 responden yang dipilih dengan menggunakan simple random sampling dari petani anggota kopi MPIG Kintamani Bali. Hasil wawancara indikator dari variabel penelitian nilai tertinggi diperoleh peremajaan tanaman dan panen kopi terendah. Hasil analisis data dengan Confirmatory Factor Analysis (CFA) dan Multiple Regression Analysis (MRA) menunjukkan bahwa ada tiga faktor budidaya yang relevan berkontribusi terhadap pencapaian produktivitas tanaman, yaitu persiapan lahan, teknik penanaman dan peremajaan tanaman. Teknik persiapan lahan dan penanaman memberikan efek positif pada produktivitas kopi arabika tetapi, peremajaan tanaman memberikan efek negatif. Teknik penanaman memiliki pengaruh paling dominan terhadap produktivitas tanaman kopi arabika. Diharapkan bahwa produksi panen kopi arabika di Bali $(0,5$ ton / Ha) kopi dapat ditingkatkan produksi kopi nasional.
\end{abstract}

Kata kunci: kopi arabika, perlindungan umum indikasi geografis, budidaya, CFA, MRA

\begin{abstract}
The aims of this study were to determine level of understanding of farmers on coffee cultivation and its effect on productivity. Observed cultivation aspect include land preparation, light intensity regulator, planting techniques, plant breeding, fertilizer application, plant pest control, plant rejuvenation and coffee harvesting aspect. This research involved 45 respondents selected by using simple random sampling from coffee member farmers of MPIG Kintamani Bali. The results of the indicator interviews of the highest value research variables obtained plant rejuvenation and lowest coffee harvest. The results of data analysis with Confirmatory Factor Analysis (CFA) and Multiple Regression Analysis (MRA) showed that there were three relevant cultivation factors contributing to the achievement of crop productivity, namely land preparation, planting techniques and plant rejuvenation. Land preparation and planting techniques gave a positive effect on productivity of arabica coffee but, plant rejuvenation gave negatively effect. Planting techniques have the most dominant influence on the productivity of arabica coffee crops. It was expected that the production of arabica coffee harvest in Bali (0.5 ton / Ha) of coffee could be improved the national coffee production.
\end{abstract}

Keywords: arabica coffee, commonity protection geographical indication, cultivation, CFA, MRA

\section{PENDAHULUAN}

Kopi Arabika Kintamani merupakan jenis kopi yang memiliki nilai jual yang tinggi di pasar dunia. Hal ini disebabkan oleh ciri khas rasa dan aroma yang tidak dimiliki jenis kopi arabika dari daerah lain. Ciri khas tersebut telah diakui dengan ditetapkannya kopi Arabika Kintamani sebagai kopi bersertifikat IG
(Indikasi Geografis). Pengakuan tersebut mengangkat nama dan nilai kopi Arabika Kintamani di pasaran lokal maupun dunia. Wilayah sentra kopi di Bali, tergabung dalam kawasan Masyarakat Perlindungan Indikasi Geografis (MPIG). Adanya perlidungan hukum atas Masyarakat Perlindungan Indikasi Geografis, maka produksi kopi di Bali dapat 
terdiferensiasi produk kopi dalam menghadapi persaingan pasar global (Anonimus, 2011). Kopi Arabika Kintamani memiliki nilai jual yang tinggi namun, produktivitas kopi masih tergolong rendah. Produksi hasil panen kopi Arabika di Kintamani tidak seragam, beberapa petani memperoleh hasil panen rendah dan beberapa petani memperoleh produksi maksimal. Hal ini disebabkan karena penerapan dan pemahaman tentang teknik budidaya yang baik dan benar belum dikuasai dengan maksimal setiap petani. Menurut Widia dan Duniaji (2016), Pemerintah Provinsi Bali menetapkan industri kopi sebagai industri agro unggulan daerah. Hal ini dikarenakan komoditi kopi arabika kintamani Bali memiliki kekhasan dan telah mempunyai pengakuan HAKI dalam bentuk sertifikasi Indikasi-Geografis (IG). Selain itu, kopi arabika kintamani termasuk kelompok speciallity coffee sehinga mendapat harga premium di pasar dunia. Arah pengembangan industri pengolahan kopi di Bali ditujukan untuk mendukung terjadinya industri pengolahan kopi yang terintegrasi sehingga dapat terjamin kesinambungan pasokan bahan baku dan berproduksi secara lebih efisien serta mampu menghasilkan produk sesuai tuntutan pasar yang dinamis. Selain itu, industri agro berbasis kopi specialty sangat potensial dikembangkan di Bali. Salah satu kendala yang dihadapi dalam menjamin kesinambungan pasokan bahan baku adalah rendahnya produktivitas hasil panen. Subiyantoro, (2016) mengatakan bahwa produktivitas tanaman kopi Arabika Kintamani hanya mencapai 590 kg kopi berasan /Ha/tahun jauh lebih rendah dari target nasional sebesar $1200 \mathrm{~kg} / \mathrm{kopi}$ berasan/Ha/tahun. Rendahnya hasil produksi panen biji kopi tidak memungkinkan meningkatkan keuntungan usaha bagi petani perkebunan kopi. Selain itu upaya percepatan hilirisasi industri kopi di Bali sulit dapat diwujudkan. Bertitik tolak dari pemapaparan diatas, penelitian ini dilakukan untuk mengetahui tingkat pemahaman petani MPIG terhadap praktek budidaya kopi arabika yang baik dan benar dan pengaruhnya terhadap produktivitas hasil panen. Tujuan penelitian ini adalah mengetahui faktor budidaya yang paling berkontribusi dalam peningkatan produktivitas tanaman kopi Arabika Kintamani. Hasil penelitian ini diharapkan dapat memberikan masukan kepada Satuan Kerja Pemerintah Daerah (SKPD) dalam upaya pelaksanaan program bimbingan teknis yang sangat dibutuhkan untuk meningkatkan pengetahuan petani.

\section{METODE}

\section{Tempat dan Waktu Penelitian}

Lokasi penelitian ini dilakukan di kawasan petani perkebunan kopi Masyarakat Perlindungan Indikasi Geografis, Kecamatan Kintamani, Kabupaten Bangli (Subak Abian di Desa Catur, Mengani, Bantang,
Blancan, Dausa dan Subak Abian Mekar Bulan Kuning. Penelitian ini dimulai pada tanggal 1 bulan September dan selesai pada tanggal 30 bulan Nopember 2017.

\section{Variabel Penelitian dan Pengukuran Data}

Penelitian ini merupakann studi pemahaman petani tentang budidaya kopi arabika dan pengaruhnya terhadap produktivitas hasil panen. Berdasarkan kajian literatur, diduga delapan faktor budidaya yang harus dipahami dan diimplementasikan oleh petani kopi untuk mendapatkan produktivitas hasil panen yang tinggi. Faktor budidaya yang berpengaruh yaitu persiapan lahan $\left[\mathrm{X}_{1}\right]$, pengatur intesitas cahaya $\left[\mathrm{X}_{2}\right]$, teknik penanaman $\left[\mathrm{X}_{3}\right]$, pembibitan tanaman $\left[\mathrm{X}_{4}\right]$, pemberian pupuk $\left[\mathrm{X}_{5}\right]$, pengendalian organisme pengganggu tanaman $\left[\mathrm{X}_{6}\right]$, peremajaan tanaman $\left[\mathrm{X}_{7}\right]$, dan panen kopi $\left[\mathrm{X}_{8}\right]$. Untuk mendapatkan informasi yang lebih rinci dan lengkap, setiap faktor budidaya dijabarkan dengan indikator-indikator pengukur. Misal X.1.1, artinya indikator 1 untuk mengukur faktor $\mathrm{X}_{1}, \mathrm{X}_{1.2}$, artinya indikator 2 untuk mengukur faktor $\mathrm{X}_{1}$, demikian juga halnya untuk faktor yang lain. Dalam penelitian ini digunakan sebanyak 45 (empat puluh lima) indikator pengukur tingkat pemahaman petani tentang faktor-faktor budidaya tanaman kopi Arabika Kintamani yang berkontribusi terhadap pencapaian produktivitas hasil panen. Setiap indikator pengukur direpresentasikan oleh satu buah pertanyaan dalam kuesioner yang dibuat dan dipergunakan sebagai alat pengumpulan data dalam penelitian ini. Indikator setiap variabel pada penetuan pernyataan pada kuesiner penelitian terdiri dari variabel persiapan lahan $\left(\mathrm{X}_{1}\right)$ terdiri dari 5 indikator, variabel pengatur intesitas cahaya $\left(\mathrm{X}_{2}\right)$ terdiri dari 5 indikator, variabel teknik penanaman $\left(\mathrm{X}_{3}\right)$ terdiri dari 7 indikator, variabel pembuatan bibit unggul $\left(\mathrm{X}_{4}\right)$ terdiri dari 6 indikator, variabel pemberian pupuk $\left(\mathrm{X}_{5}\right)$ terdiri dari 6 indikator, variabel pengendalian OPT $\left(\mathrm{X}_{6}\right)$ terdiri dari 7 indikator, variabel peremajaan tanaman $\left(\mathrm{X}_{7}\right)$ terdiri dari 5 indikator dan variabel panen kopi $\left(\mathrm{X}_{8}\right)$ yang teriri dari 4 indikator sehingga jumlah total indikator pada kuesioner menjadi 45 pernyataan. Pemberian skor untuk ukuran indikator pengukur tingkat pemahaman petani menggunakan skala ordinal dengan 5 peringkat skala pengukuran. Skor 1= tidak paham, Skor 2= kurang paham, Skor 3= ragur-ragu, skor $4=$ paham, skor 5= sangat paham.

\section{Responden Penelitian dan Pengumpulan Data}

Responden dalam penelitian ini adalah individuindividu petani kopi yang terdaftar sebagai anggota koperasi tani MIPG Kintamani Bali yang memiliki luas kebun kopi minimal $0,5 \mathrm{Ha}$ dan telah pernah mendapatkan pembinaan dari Dinas Perkebunan Provinsi Bali. Berdasarkan informasi yang didapat dari pengurus koperasi MPIG Kintamani Bali tercatat 
sebanyak 450 orang petani kopi sebagai anggota yang berasal dari 5 wilayah subak abian. Selanjutnya ukuran populasi dalam penelitian ini dinyatakan 450 orang petani kopi. Penetuan individu-individu petani yang terpilih sebagai responden penelitian untuk mewakili populasi digunakanlah teknik pengambilan sampel secara acak sederhana (simple random sampling). Jumlah individu petani yang dijadikan responden dalam penelitian yaitu sebanyak 45 orang, yaitu $10 \%$ dari ukuran populasi untuk memenuhi syarat kecukupan sampel terhadap populasi yang diwakili (Siregar, 2012; Singarimbun et al., 1989). Setiap responden diberikan pertanyaan-pertanyaan seperti yang termuat pada kuesioner dan diminta untuk memberikan jawaban atas pertanyaan tersebut dalam 5 pilihan jawaban. Sebelum diberi pertanyaan, terlebih dahulu responden diberikan penjelasan sekilas tentang maksud dan tujuan penelitian, maksud pertanyaan dan cara memberikan jawaban. Dalam hal ini, pengumpulan data dilakukan dengan metode wawancara secara langsung.

\section{Analisis Data}

Analisis data dilakukan setelah tahapan penelitian dan data penelitian didapatkan. Kuisioner yang telah lengkap berisikan jawaban pada setiap pernyataan, maka terlebih dahulu dilakukan tabulasi data yang disusun dalam bentuk matrik data yang berukuran (nxp), yang mana $\mathrm{n}=$ banyaknya responden, dan $\mathrm{p}=$ banyaknya indikator pengukur). Analisis yang dilakukan sebelum dilakukan analisis CfA dan statistik multivariat, terlebih dahulu dilakukan uji validitas dan reabilitas data. Uji validitas data dilakukan untuk mengetahui indikator yang digunakan pada kuesioner teruji kelayakannya (sah atau tidak sah) sedangkan uji reliabilitas dilakukan untuk mengetahui bahwa alat ukur yang digunakan teruji kehandalan atau konsitensi alat ukur teruji. Uji validitas data menggunakan statistik korelasi bivariat Pearson. Dasar pengambilan keputusan adalah membandingkan nilai korelasi hitung (r-hitung) dengan nilai korelasi tabel (r-tabel) pada tingkat signifikasni $\alpha=0,05$, yang mana jika r-hitung > rtabel, maka item angket berkorelasi signifikan dengan skor total (item angket dinyatakan valid). Sebaliknya, jika r-hitung < r-tabel, maka item angket dinyatakan tidak valid dan selanjutnya tidak diikutkan dalam analisis data tahap berikutnya. Uji Reliabilitas data menngunakan stastistik Alpha-Cronbach. Dasar pengambilan keputusan adalah membandingkan nilai Alpha-Cronbach-hitung dengan kriteria. Jika nilai Alpha-Cronbach bernilai 0,80 - 1,00 maka reliabilitas indikator dikatakan sangat tinggi; jika nilai AlphaCronbach bernilai $0,60-0,80$ maka reliabilitas indikator dikatakan tinggi; jika nilai Alpha-Cronbach bernilai 0,40 - 0,60 maka reliabilitas dikatakan sedang; dan jika nilai Alpha-Cronbach bernilai 0,20 -
0,40 maka reliabilitas dikatakan rendah (Nugroho,2013). Data yang telah dinyatakan valid selanjutnya dianalisis menggunakan analisis statistik data multivariate, yaitu Confirmatory Factor Analyses (CFA) dan Analisis Regresi Linier Berganda (MRA). Analisis CFA diperlukan untuk menemukan faktor-faktor budidaya yang relevan berkontribusi terhadap pencapaian produktivitas hasil panen kopi arabika dengan ekstraksi Analisis Komponen Utama dan mensinkronasikan faktorfaktor yang terbentuk dengan variabel konstruk yang menjelaskannya dipilih metode rotasi factor varimax sehingga hasil dari uji CFA menghasilkan variabel yang memiliki bobot tertinggi pada faktor baru yang terbentuk dan ddapat mewakili anggota variabel lainnya. Sedangkan analisis MRA (Multiple Regression Analyses) diperlukan untuk mengetahui sejauh mana besar pengaruh dan arah pengaruh faktor budidaya yang relevan hasil dari uji analisis CFA tersebut terhadap produktivitas hasil panen Kopi Arabika Kintamani Bali.

\section{HASIL DAN PEMBAHASAN}

\section{Pemahaman Petani Tentang Budidaya Kopi Arabika}

Dalam penelitian ini ruang lingkup budidaya kopi arabika direpresentasikan oleh delapan variabel konstruk, yaitu persiapan lahan [X1], pengatur intesitas cahaya [X2], teknik penanaman [X3], pembibitan tanaman [X4], pemberian pupuk [X5], pengendalian organisme pengganggu tanaman [X6], peremajaan tanaman [X7], dan panen kopi [X8]. Tingkat pemahaman petani terhadap setiap variabel konstruk tertentu didapat dari rata-rata total tertimbang skor penilaian seluruh responden untuk seluruh indikator pengukurnya. Dalam hal ini, nilai variabel konstruk tidak didapat secara langsung dari responden melainkan didapat melalui skor penilaian terhadap indikator pengukurnya. Karena itu, sebelum dilakukan penghitungan terhadap rata-rata tingkat pemahaman petani terhadap setiap variabel konstruk terlebih dauhulu dilakukan ujia validitas dan realibilitas data. Hasil uji validitas data menunjukkan bahwa ada sejumlah indicator pengukur yang mengandung data yang tidak valid, dengan kriteria $r-$ hitung < r-tabel $(\alpha=0,05 ; \mathrm{df}=45)$, yang mana nilai $\mathrm{r}$ tabel $=0,294$. Adapun hasil analisis dapat disajikan pada Tabel 1.

Tabel 1.

Daftar indikator pengukur yang tidak valid 


\begin{tabular}{lcl}
\hline \multirow{2}{*}{ Kode Indikator } & \multicolumn{2}{c}{ Nilai } \\
\cline { 2 - 3 } & r-hitung & r-tabel \\
\hline $\mathrm{X}_{1.3}$ & 0,202 & 0,294 \\
$\mathrm{X}_{2.3}$ & 0,218 & 0,294 \\
$\mathrm{X}_{3.7}$ & 0,021 & 0,294 \\
$\mathrm{X}_{4.4}$ & 0,283 & 0,294 \\
$\mathrm{X}_{4.5}$ & 0,057 & 0,294 \\
$\mathrm{X}_{6.4}$ & 0,205 & 0,294 \\
$\mathrm{X}_{6.6}$ & 0,207 & 0,294 \\
$\mathrm{X}_{7.4}$ & 0,087 & 0,294 \\
\hline
\end{tabular}

Berdasarkan Tabel 1. terdapat sebanyak 8 (delapan) indikator pengukur yang dinyatakan tidak valid, yaitu $\mathrm{X}_{.1 .3}, \mathrm{X}_{2.3}, \mathrm{X}_{3.7}, \mathrm{X}_{4.4}, \mathrm{X}_{4.5}, \mathrm{X}_{6.4}, \mathrm{X}_{6.6}$ dan $\mathrm{X}_{7.4}$. Sesuai ketentuan statistik, data tersebut tidak diikutkan dalam analisis lebih lanjut. Karena itu indikator pengukur faktor-faktor budidaya tanaman kopi arabika yang berkontribusi terhadap pencapaian produktivitas hasil panen berjumlah 37 (tiga puluh tujuh) buah. Data yang valid harus didukung oleh angket yang handal atau terpercaya. Berdasarkan hasil analisis reliabilitas menggunakan program SPSS versi 16.0 didapatkan bahwa nilai statistic AlphaCronbach $=0,945$. Jika diperbandingkan dengan kriteria, maka realiabilitas data dalam penelitian dapat dikatakan sangat tinggi, yaitu berada dalam angka statistik Alpha-Cronbach pada kisaran 0,801,00 yangmasuk dalam kategori kehandalan tingkat tinggi. Penghitungan terhadap rata-rata tingkat pemahaman petani terhadap setiap variabel konstruk didasarkan pada skor penilaian indikator pengukur yang telah dinyatakan valid dan reliable (handal) berdasarkan uji statistic yang sudah dilakukan. Berdasarkan hasil uji validitas dengan 8 indikator yang tidak valid dan menddapatkan kehandalan data yang dangat tinggi sehingga nilai rata-rata tingkat pemahaman petani yang berjumlah 37 indikator pada setiap variabel konstruk disajikan seperti pada Gambar 1.

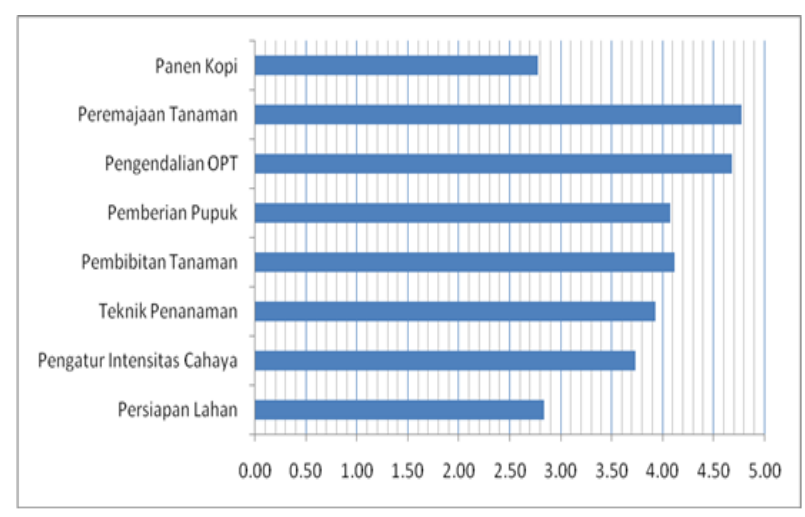

Keterangan:
$\mathrm{X}=(1=$ sangat tidak paham, $2=$ kurang paham, $3=$ raguragu, $4=$ paham, $5=$ sangat paham)

Gambar 1. Grafik hasil rata-rata nilai konstruk pemahaman petani

Berdasarkan pada Gambar 1, terlihat petani kopi pada kawasan Masyarakat Perlindungan Indikasi Geografis (MPIG) memiliki tingkat pemahaman paling tinggi terhadap variabel Peremajaan tanaman yaitu dengan nilai rata sebesar 4,77, Tingkat pemahaman paling rendah terhadap variabel panen kopi yaitu sebesar rata-rata sebesar 2,78. Sedangkan rata-rata tingkat pemahaman secara umum terhadap seluruh variabel-variabel konstruk yaitu sebesar 3,8. Hal ini menunjukkan tingkat pemahaman petani kopi Arabika Kintamani secara umum terhadap aspek budidaya belum mencapai criteria paham. Karena hasil nilai konstruk tidak lebih dari atau sama dengan 4 (paham) sesuai keterangan dari skala likert. Upaya peningkatan produtivitas hasil panen kopi diperlukan pemahaman secara benar pada setiap faktor budidaya agar petani dapat mengambil keputusan dalam menyelesaikan masalah yang dihadapi. Menurut van den Berg dan Jiggins (2007) dengan pelatihan meningkatkan pemahaman petani dampaknya akan mengembangkan kreativitas dalam usaha tani yang digeluti petani. Pemhaman sesuai standar yang telah disarankan harus dikuasai dan diterapkan maksimal terhadap komoditi uasahatani yang dimiliki agar bisa mencapai hasil produksi yang maksimal.

\section{Faktor-Faktor Budidaya yang Relevan}

Berdasarkan kajian literatur diduga ada sebanyak delapan variabel konstruk yang mempunyai keterkaitan dengan tingkat produktivitas hasil panen kopi, yaitu persiapan lahan $\left[\mathrm{X}_{1}\right]$, pengatur intesitas cahaya $\left[\mathrm{X}_{2}\right]$, teknik penanaman $\left[\mathrm{X}_{3}\right]$, pembibitan tanaman $\left[\mathrm{X}_{4}\right]$, pemberian pupuk $\left[\mathrm{X}_{5}\right]$, pengendalian organisme pengganggu tanaman $\left[\mathrm{X}_{6}\right]$, peremajaan tanaman $\left[\mathrm{X}_{7}\right]$, dan panen kopi $\left[\mathrm{X}_{8}\right]$. Untuk mengetahui faktor-faktor budidaya manakah yang paling relevan memberikan konstribusi dalam pencapaian tingkat produktivitas hasil panen digunakanlah metode statistik multivariate yaitu: Confirmatory Factor Analyses (CFA) yaitu sebuah teknik melakukan reduksi data. Dalam penelitian ini analisis CFA, menggunakan input data berupa matrik korelasi variabel konstruk yang burukuran $(8 \times 8)$ dan metode ekstraksi yang dipilih yaitu metode Principle Componen Analysis (PCA). Untuk mensinkronasikan faktor-faktor yang terbentuk dengan variabel konstruk yang menjelaskannya dipilih metode rotasi faktor yaitu metode Varimax. Hasil analisis CFA menunjukkan bahwa dari delapan variabel konstruk yang diikutkan ke dalam proses ekstraksi data dengan metode Principle Component Analyses (PCA) didapatkan distribusi keragaman (variansi) pada 
setiap variabel baru (faktor) yang terbentuk adalah seperti pada Tabel 2.

Tabel 2. Distribusi keragaman setiap faktor

\begin{tabular}{cccc}
\hline \multirow{4}{*}{ Faktor } & \multicolumn{3}{c}{ Eigenvalue (Akar karateristik) } \\
\cline { 2 - 4 } & Nilai & Variansi \\
& eigenvalue & $(\%)$ & \\
\hline $\mathbf{1}$ & $\mathbf{4 , 3 9 9}$ & $\mathbf{5 4 , 9 8 8}$ & $\mathbf{5 4 , 9 8 8}$ \\
$\mathbf{2}$ & $\mathbf{1 , 3 6 5}$ & $\mathbf{1 7 , 0 6 7}$ & $\mathbf{7 2 , 0 5 5}$ \\
$\mathbf{3}$ & $\mathbf{1 , 0 0 0}$ & $\mathbf{1 2 , 5 0 6}$ & $\mathbf{8 4 , 5 6 1}$ \\
4 & 0,470 & 5,879 & 90,440 \\
5 & 0,314 & 3,928 & 94,368 \\
6 & 0,230 & 2,881 & 97,249 \\
7 & 0,134 & 1,673 & 98,922 \\
8 & 0,086 & 1,078 & 100,000 \\
\hline
\end{tabular}

Keterangan: Metode ekstraksi: Principle Component Analyses (PCA)

Tabel 2. Menunjukkan komponen berkisar antara komponen 1 hingga 8 yang mewakili jumlah variabel bebas. Penentuan jumlah faktor baru terbentuk dilihat pada kolom tabel Initial Eigen Value yang ditetapkan jumlah faktor baru yang terbentuk jika memiliki nilai sesuai ketentuan statistik analisis faktor, suatu variabel baru (faktor) dapat dikatakan relevan dalam pemodelan CFA jika faktor tersebut mempunyai nilai eigenvalue $\geq 1,000$. Makin tinggi nilai eigenvalue suatu faktor, makin tinggi pula tingkat keutamaan (kontribusi) faktor dalam model CFA. Hal ini sejalan dengan principle of pairsimony yang menyatakan bahwa semakin sederhana sebuah model statistik untuk menjelaskan sebuah fenomena, semakin baik pula model statistik tersebut. Berdasarkan prinsip ini model CFA budidaya kopi arabika dalam kaitannya produktivitas hasil panen dapat dijelaskan dengan tiga faktor. Seperti pada Tabel 2, ada tiga faktor yang relevan dalam kaitannya dengan produktivitas hasil panen, yaitu faktor 1, (nilai eigen value $=4,399$, dan mampu menjelaskan $54,988 \%$ total informasi), faktor 2 (nilai eigen value $=1,365$, dan mampu menjelaskan $17,067 \%$ total informasi) dan faktor 3 (nilai eigen value $=1,000$ dan mampu menjelaskan $12,506 \%$ total informasi. Total informasi yang dapat dijelaskan oleh model CFA budidaya kopi arabika adalah sebesar $84,561 \%$. Sebagai implikasi dari reduksi variabel dalam model CFA terdapat 15,439\% informasi yang tidak dijelaskan dalam model. Dalam analisis CFA, selain dikenal dengan nilai eigenvalue juga dikenal nilai bobot faktor (loading factor). Nilai bobot berkisar pada angka $0.00-1.00$, yang mana bila suatu variabel konstruk mempunyai bobot dengan angka $=$ 0.00 terhadap suatu faktor tertentu, maka variabel konstruk itu tidak mempunyai sumbangan dalam mewakili faktor tersebut. Sebaliknya, jika mempunyai bobot dengan angka $=1,00$ terhadap suatu faktor tertentu, maka variabel konstruk itu mempunyai sumbangan yang sempurna dalam mewakili faktor tersebut. Dalam statistic CFA, berlaku kenentuan bahwa suatu variabel konstruk dinyatakan relevan mewakili faktor tertentu jika variabel tersebut memunyai angka bobot faktor > 0,50 dan sebaliknya jika variabel tersebut kurang dari 0,50 tidak bisa mewakili variabel yang memiliki bobot nilai lebih dari 0,50 sehingga variabel tersebut masuk dalam anggota variabel yang memiliki nilai bobot tertinggi. Besaran angka bobot faktor setiap variabel konstruk dalam model CFA budidaya kopi arabika ini disajikan pada Tabel 3.

Tabel 3. Anggota bobot faktor variabel konstruk dalam model CFA budidaya kopi arabika

\begin{tabular}{cccc}
\hline \multirow{2}{*}{$\begin{array}{c}\text { Kode } \\
\text { variabel }\end{array}$} & \multicolumn{3}{c}{ Angka bobot factor } \\
\cline { 2 - 4 } $\mathbf{X}_{\mathbf{3}}$ & Faktor 1 & Faktor 2 & Faktor 3 \\
$\mathbf{X}_{5}$ & 0,785 & 0,248 & 0,107 \\
$\mathbf{X}_{2}$ & 0,785 & 0,066 & 0,402 \\
$\mathbf{X}_{4}$ & 0,784 & 0,069 & 0,118 \\
$\mathbf{X}_{7}$ & 0,099 & $\underline{\mathbf{( 0 , 9 5 3 )}}$ & 0,322 \\
$\mathbf{X}_{6}$ & 0,318 & 0,884 & 0,118 \\
$\mathbf{X}_{\mathbf{1}}$ & 0,156 & 0,266 & $\underline{\mathbf{( 0 , 8 8 3}}$ \\
$\mathbf{X}_{8}$ & 0,357 & 0,022 & 0,852 \\
\hline
\end{tabular}

Tabel 3, menjelaskan variabel konstruk $\mathrm{X}_{3}$ (teknik penanaman) terpilih mewakili faktor 1 (angka bobot faktor $=0,910$ ), variabel konstruk $\mathrm{X}_{7}$ (peramajaan tanaman) terpilih mewakili faktor 2 (angka bobot faktor $=0,953$ ) dan variabel konstruk $X_{1}$ (persiapan lahan) terpilih mewakili faktor 3 (angka bobot faktor $=0,883$ ). Berdasarkan hasil analisis ini dapat disimpulkan bahwa faktor-faktor budidaya kopi arabika yang relevan berkontribusi dalam pencapaian produkvitas hasil panen adalah teknik persiapan lahan, teknik penanaman dan peremajaan tanaman. Sedangkan faktor-faktor lain seperti pemberian pupuk, pengatur intensitas cahaya, pembibitan tanaman, pengendalian OPT dan panen kurang relevan terhadap pencapaian produkvitas hasil panen.

\section{Pengaruh Budidaya Terhadap Produktivitas}

Berdasarkan analisis CFA, telah terindentifikasi tiga faktor yang relevan dalam kaitannya dengan produktivitas hasil panen, yaitu persiapan lahan, teknik penanaman dan peremajaan tanaman. Tiga variabel tersebut diasumsikan dapat mewakili kedelapan variabel lainnya. Untuk mengetahui bagaimana dan sejauh mana pengaruh masing- 
masing faktor budidaya yang relevan tersebut terhadap naik turunya produktivitas hasil panen, maka dilakukan analisis menggunakan metode Multiple Regression Analyses (MRA). Dalam pemodelan MRA ini, produktivitas hasil panen diperlakukan sebagai variabel dependen (terikat) dan persiapan lahan $\left(\mathrm{X}_{1}\right)$, teknik penanaman $\left(\mathrm{X}_{3}\right)$ dan peremajaan tanaman $\left(\mathrm{X}_{7}\right)$ diperlakukan sebagai model independen (bebas) dan produktivitas hasil panen (Y) variabel terikat. Sehingga, dalam model MRA ini terdapat empat variabel, yaitu satu variabel dependen dan tiga buah variabel independen. Adapun model umum persamaan linier MRA dalam penelitian ini, yaitu:

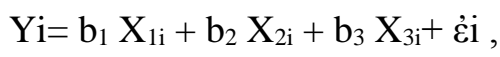

yang mana:

$\mathrm{Y}=$ tingkat produktivitas hasil panen kopi arabika (kg kopi beras/Ha/tahun) responden ke-i

$\mathrm{X}_{1 \mathrm{i}}=$ rata-rata skor pemahaman tentang persiapan lahan tanam kopi arabika responden ke-i

$\mathrm{X}_{3 \mathrm{i}}=$ rata-rata skor pemahaman tentang teknik penanaman kopi arabika responden ke-i

$\mathrm{X}_{7 \mathrm{i}}=$ rata-rata skor pemahaman tentang peremajaan kopi arabika responden ke-i

$b_{1}, b_{2}$ dan $b_{3}=$ angka koefisien regresi masing-masing variabel

غ̇i = residu model

Hasil analisis sidik ragam (Tabel 4) menunjukkan bahwa hubungan variabel independen $X_{1}, X_{3}$ dan $X_{7}$ terhadap variabel dependen $\mathrm{Y}$ dapat dinyatakan dengan persamaan regresi liner berganda. Artinya, variabel $\mathrm{X}_{1}, \mathrm{X}_{3}$ dan $\mathrm{X}_{7}$ berpengaruh linier terhadap variabel terikat.

Tabel 4. Hasil sidik ragam model regresi liner produktivitas hasil panen kopi arabika

\begin{tabular}{lrrr}
\hline Model & $\begin{array}{c}\text { Derajat } \\
\text { bebas } \\
(\mathrm{db})\end{array}$ & $\begin{array}{c}\text { F- } \\
\text { Hitung }\end{array}$ & Signifikansi \\
\hline $\begin{array}{l}\text { Regression } \\
\text { Residual }\end{array}$ & 3 & 24,226 & $0,000^{\mathrm{a}}$ \\
\hline
\end{tabular}

Berdasarkan Tabel 4 diperoleh hasil yang digunakan untuk uji kelayakan model regresi (uji F). Uji kelayakan model merupakan tahap awal mengidentifikasi model regresi yang diestimasi layak atau tidak layak (Iqbal, 2015). Model yang diestimasi layak digunakan untuk menjelaskan pengaruh variabel-variabel bebas terhadap variabel terikat. Dalam pengujian menggunakan program SPSS keterangan hasil diambil apabila nilai signifikansi (kolom signifikansi pada tabel 4) lebih kecil dari tingkat kesalahan dengan nilai alpha 0,05 maka model regresi yang diestimasi dikatakan layak diinterpretasikan dalam pengaruhnya terhadap variabel terikat. Persamaan regresi sudah dinyatakan layak dalam penentuan arah pengaruhnya terhadap variabel terikat. Arah pengaruhnya dilihat dari tanda pada koefisien setiap variabel bebas. sehingga persamaan regresi yang didapat dilihat pada persamaan 2 dan model regresi yang didapat adalah sebagai berikut:

$\mathrm{Yi}=0,178 \mathrm{X}_{1 \mathrm{i}}+0,770 \mathrm{X}_{3 \mathrm{i}}-0,152 \mathrm{X}_{7 \mathrm{i}}+\dot{\varepsilon} \mathrm{i}, \ldots \ldots \ldots \ldots$

Persamaan 2. Menjelaskan besaran koefisien setiap variabel yang diuji. Besaran koefisien didapat dari output hasil uji Multiple Regression Analyses menggunakan program SPSS versi 16.0 pada tabel output coeficient. Nilai koefisien tersebut digunakan dalam menginterprestasikan besar arah pengaruh variabel bebas terhadap variabel terikat. Tanda besaran (koefisien variabel) dapat bernilai positif dan negatif yang artinya jika bernilai positif menunjukkan arah hubungan yang searah antara variabel bebas terhadap variabel terikat. Tanda besaran yang bernilai negatif artinya arah hubungan tidak searah antaravariabel bebas dengan variabel terikat (Iqbal, 2015). Berdasarkan persamaan 2, terlihat variabel Persiapan lahan $\left(\mathrm{X}_{1}\right)$ berpengaruh positif terhadap produktivitas, variabel Teknik penanaman berpengaruh $\left(\mathrm{X}_{3}\right)$ positif terhadap variabel produktivitas, dan variabel Peremajaan tanaman $\left(\mathrm{X}_{7}\right)$ berpengaruh negatif terhadap variabel produktivitas. Hal ini diartikan bahwa, peningkatan pemahaman dalam persiapan lahan tanam meningkatkan produktivitas hasil panen kopi arabika, peningkatan pemahaman tentang teknik penanaman kopi meningkatkan produkvitas hasil panen kopi arabika dan peningkatan pemahaman tentang peremajaan tanaman menurunkan produktivitas hasil panen kopi arabika. Berdasarkan angka koefisien regresi, variabel Teknik penanaman mempunyai nilai paling besar yang artinya mempunyai pengaruh yang paling dominan dibandingkan kedua variabel lainnya.

\section{Pengaruh Persiapan Lahan Terhadap Produkvitas Hasil Panen Kopi Arabika}

Pemilihan lahan secara umum dilakukan untuk tanaman pertanian khususnya pada tanaman kopi Robusta, Arabika dan Liberika mempunyai karakteristik yang sama. Karakteristik utama pada tanaman tersebut adalah kemiringan tanah yang kurang dari 30\%. Pembukaan lahan diawali dari melakukan penebangan dan pembongkaran terhadap pohon perdu dan tunggul beserta perakarannya (Puslitbangbun, 2017). Hal ini dilakukan agar nantinya pohon kopi yang ditanam dapat diatur dalam jarak penanamannya. Persiapan lahan pada 
prinsipnya membebaskan lahan dari tumbuhan pengganggu atau komponen lain dengan maksud untuk memberikan ruang tumbuh kepada tanaman kopi yang akan dibudidayakan (Prasetyo, 2008). Pada penelitian ini, data diperoleh dari aspek pemahaman petani kopi arabika di Kintamani tentang variabel budidaya yang berpengaruh terhadap produktivitas kopi di Kintamani yang masih ditingkat rendah. Menurut (Prasetyo, 2008) persiapan lahan sangat penting dalam meningkatkan produktivitas karena tanaman kopi dapat tumbuh dengan baik tanpa terganggu oleh tanaman lainnya atau tanaman sebelumnya. Variabel persiapan lahan dari hasil uji regresi linier berganda berpengaruh positif pada perkebunan kopi di Kintamani. Dalam hal ini, disebabkan pada tingkat keterampilan petani kopi di Kintamani tentang persiapan lahan sudah dipahami petani. Dengan rata-rata luasan lahan yang dimiliki petani kopi Arabika Kintamani penerapan persiapan lahan yang baik dan benar tidak menjadi kendala bagi petani di Kintamani.

\section{Pengaruh Teknik Penanaman Terhadap Produktivitas Hasil Panen Kopi Arabika}

Penanaman adalah kegiatan yang dilakukan setelah bibit siap dipindah ke tempat atau lahan yang sudah disiapkan. Dalam hal ini khususnya pada tanaman kopi, penanaman berkaitan dengan jarak tanam antar pohon, lubang tanam, dan waktu tanam sehingga dalam luasan areal tanam dapat dimaksimalkan lubang tanam yang berukuran 40 sampai $60 \mathrm{~cm}$ (Puslitkoka, 2006). Pada penelitian ini, data teknik penanaman diperoleh dari aspek persepsi petani kopi arabika di Kintamani tentang variabel budidaya yang berpengaruh terhadap produktivitas kopi di Kintamani yang masih ditingkat rendah. Dari hasil uji yang sudah dilakukan variabel teknik penanaman termasuk variabel yang memiliki bobot nilai tertinggi pada komponen satu yang terbentuk (uji konfirmatori). Pada uji regresi didapat variabel ini berpengaruh signifikan terhadap peningkatan produktivitas kopi arabika. Variabel teknik penanaman erpengaruh signifikan artinya dari persepsi petani bahwa dalam upaya peningkatan produktivitas dilakukan teknik penanaman yang benar. Dalam hal ini yang dimaksud adalah untuk mendapat peningkatan produktivitas besar dipengaruhi oleh jarak tanam kopi, persiapan tanam yang baik, dan maksimalnya penerapan sistem tumpang sari sudah diketahui petani kopi di Kintamani dari pengalaman bertani yang cukup lama. Teknik penanaman yang baik dan benar menjadi awal perkembangan tanaman kopi agar tumbuh dengan baik. Pertumbuhan tanaman yang baik diasumsikan akan dapat berproduktivitas maksimal. Jadi dengan hasil uji yang menyatakan bahwa penerapan teknik penanaman berpengaruh signifikan terhadap produktivitas artinya petani kopi arabika di Kintamani menguasai pemahaman tentang teknik penanaman. Selain itu, variabel teknik penanaman memiliki koefisien tertinggi diandingkan dua variabel lainnya. Dalam hal ini artinya menurut persepsi petani yang memeri pengaruh dominan terhadap peningkatan produktivitas apabila variabel budidaya (teknik penanaman) dilakukan dengan baik dan benar.

\section{Pengaruh Peremajaan Tanaman Terhadap Produktivitas Hasil Panen Kopi Arabika}

Peremajaan tanaman merupakan suatu tindakan yang dilakukan yaitu dengan mengganti tanaman yang rusak atau tanaman yang tidak menghasilkan. Dalam hal ini, peremajaan pada tanaman kopi juga dilakukan dengan cara memotong cabang yang nonproduktif (Puslitkoka, 2006). Menurut Susanto (1994) pemangkasan bertujuan untuk meningkatkan produktivitas, mempertahankan umur ekonomis tanaman (peremajaan) juga dapat mengendalikan hama penyakit pada tanaman. Pemangkasan juga dapat dimanfaatkan untuk mencapai efisiensi sina matahari sehingga tanaman mampu mencapai produktivitas dengan maksimal (Parwoto et al., 2008). Teknik pemangkasan dalam pelaksanaanya ada beberapa macam yaitu; pemangkasan bentuk, pemangkasan pemeliharaan dan pemangkasan produksi yang memacu pertumbuhan bunga dan buah (Puslitkoka, 2004). Pada penelitian ini, data diperoleh dari aspek persepsi petani kopi arabika di Kintamani tentang variabel budidaya yang berpengaruh terhadap produktivitas kopi di Kintamani yang masih ditingkat rendah. Dari hasil uji yang sudah dilakukan variabel peremajaan tanaman termasuk variabel yang memiliki bobot nilai tertinggi pada komponen dua yang terbentuk (uji konfirmatori). Pada uji regresi didapat variabel ini berpengaruh negatif terhadap produktivitas kopi arabika. Pengaruh negatif ini artinya pemangkasan apabila dilakukan tetapi member dampak penrunan produksi padahal secara teori pemangkasan dapat meningkatkan produktivitas tanaman. Pelaksanaan pemangkasan (peremajaan tanaman) secara umum sudah dilakukan oleh petani kopi di Kintamani. Petani memahami bahwa pemangkasan berpengaruh terhadap produktivitas tetapi sebagian besar dalam pelaksanaannya belum dilakukan oleh petani. Pemangkasan yang belum dilakukan dapat dilihat dari rata-rata produksi kopi di Kintamani masih terbilang rendah. Hal ini, disebabkan teori pemangkasan yang baik dan benar belum dikuasai dan petani tidak mau mengeluarkan biaya tambahan untuk tenaga kerja dalam pelaksanaan pemangkasan. Faktor penyebab variabel peremajaan tanaman bernilai negatif juga dikarenakan tingkat pemahaman teori yang baik dan benar petani masih dapat dikatakan rendah. Selain itu, 
peremajaan tanaman memerlukan proses yang cukup panjang. Sedangkan sebagian besar petani kopi di Kintamani memiliki pekerjaan selain menjadi petani (petani bukan pekerjaan utama). Pemangkasan dilakukan lebih dari satu kali untuk luasan perhektar dalam setahun. Jika petani tidak berani mempekerjakan karyawan dan memiliki pekerjan lain selain petani maka, pemangkasan tidak akan dapat dilakukan secara merata pada setiap pohon kopi.

\section{KESIMPULAN DAN SARAN \\ Kesimpulan}

Berdasarkan hasil analisis yang telah dilakukan dalam penelitian, maka dapat dieroleh kesimpulan sebagai berikut:

1. Dari 8 variabel yang diuji dihasilkan 3 variabel baru yang mewakili. Artinya 3 variabel baru tersebut yang mewakili sebagai pemberi pengaruh terhadap produktivitas kopi arabika di Kintamani. Variabel tersebut adalah teknik penanaman (X3), peremajaan tanaman (X7) dan persiapan lahan (X1).

2. Dari 3 variabel yang teruji terdapat variabel yang paling dominan berpengaruh terhadap produktivitas yakni variabel teknik penanaman.

\section{Saran}

Berdasarkan hasil analisis yang telah dilakukan dalam penelitian, maka dapat dieroleh kesimpulan sebagai berikut:

1. Pelatihan khusus kepada petani perlu diberikan dalam pelaksanaan peremajaan tanaman kopi. Kegiatan tersebut berupa pelatihan pemangkasan kedaerah kebun kopi nasional yang memiliki hasil produksi tinggi.

2. Pemahaman petani akan pelaksanaan teknik penanaman sudah dikuasai dengan baik dan benar. Jadi, variabel teknik penanaman dapat direkomendasi keseluruh petani agar memaksimalkan proses teknik penanaman yang baik dan benar dalam upaya peningkatan hasil prouktivitas pohon kopi arabika di Kintamani Bali sehingga rata-rata produktivitas kopi di Kintamani (0,5 ton/ha) bisa mencapai produktivitas rata-rata kopi nasional (1,2 ton/ha).

\section{DAFTAR PUSTAKA}

Anonimus. 2011. Buku Persyaratan Indikasi Geografis Kopi Kintamani Bali. Masyarakat Perlindungan Indikasi Geografis Kopi Kintamani Bali, Denpasar.

Berg, H.V.D. dan J. Jiggins. 2007. Investing in farmers-the impacts of farmer field schools in relation to integrated pest management. World Development, 35 (4): 663-686.
Iqbal, M. 2015. Pengolahan Data dengan Regresi Linier Berganda dengan SPSS. https://dosen.perbanas.id/regresi-linierberganda-denganspss/. Diakses pada tanggal: 13 Januari 2018

Nugroho, S. 2013. Cara Menghitung Uji Validitas dan Uji Reliabilitas Instrumen Skripsi Kuantitatif dengan Menggunakan SPSS. http://devamelodica.com/ cara- menghitunguji-validitas-dan-uji-reliabilitas-instrumenskripsi-kuantitatif-dengan-spss/. Diakses tanggal: 6 Januari 2018.

Prasetyo, B. dan L. M. Jannah. 2008. Metode Penelitian Kuantitatif: Teori dan Aplikasi. PT Raja Grafindo Persada, Jakarta.

Prawoto, A. A. dan R. Erwiyono. 2008. Potensi Budidaya Kakao Untuk Pembangunan Ekonomi di Aceh Barat. Pusat Penelitian Kopi dan Kakao Indonesia.

Prawoto, A. A. 1996. Pengaruh Pangkasan Bentuk Tanaman Kakao Asal Setek Cabang Plagiotrop terhadap Pertumbuhan dan Hasil Buah. Pelita Perkebunan. 12(3): 119-126.

Pusat Penelitian, Pengembangan dan Perkebunan. 2010. Budidaya dan Pascapanen Kopi. Kementerian Pertanian, Bogor.

Puslitkoka. 2004. Panduan Lengkap Budidaya Kakao. Pusat Penelitian Kopi dan Kakao Indonesia. PT Agromedia Pustaka, Jakarta.

Puslitkoka. 2006. Pedoman Teknis Tanaman Kopi. Pusat Penelitian Kopi dan Kakao Indonesia, Jember.

Singarimbun dan Masri. 1989. Metode Penelitian Survey. LP3S, Jakarta.

Siregar, S. 2012. Metode Penelitian Kuantitatif Dilengkapi Dengan Perbandingan. Prenadamedia Group, Jakarta.

Susanto. 1994. Teknologi Pengolahan Hasil Pertanian. PT Bina Ilmu, Surabaya.

Syofian. 2012. Statistika Deskriptif untuk Penelitian: Dilengkapi Perhitungan Manual dan Aplikasi SPSS Versi 17. Rajawali Pers, Jakarta.

Widia, I.W. dan A.S. Duniaji. 2016. Akselerasi Pengembangan Industri Agro Kopi Provinsi Bali. Makalah disampaikan pada acara FGD Stakeholders IKM Kopi. Dinas Perindustrian 
dan Perdagangan Pemerintah Daerah Provinsi Bali. 